\title{
Risk Management Practices towards Developments of Sport and Recreational Activities in Malaysia
}

\author{
Jaffry Zakaria1,2, Mohd Taib Harun1, Norlena Salamuddin'1, Md. Amin Md. Taff ${ }^{2}$ \\ ${ }^{1}$ Faculty of Education, National University of Malaysia, Bangi, Malaysia \\ ${ }^{2}$ Faculty of Sport Science \& Coaching, Sultan Idris Education University, Tanjung Malim, Malaysia \\ Email: jaffry@fsskj.upsi.edu.my
}

Received 6 June 2016; accepted 9 July 2016; published 12 July 2016

Copyright (C) 2016 by authors and OALib.

This work is licensed under the Creative Commons Attribution International License (CC BY).

http://creativecommons.org/licenses/by/4.0/

(c) (i) Open Access

\begin{abstract}
Sports and recreation activities are always exposed to various safety issues before, during and after activities. Positive practices could avoid the occurrence of accidents that caused injuries to the participants. Risk management practices are the most important element in the organization or management of sports and recreation activities. This element is significant in increasing the wellbeing of a society where a safe and healthy population can be developed. Each activity that was about to be organized and the facilities provided must be free and safe from incidents that could cause injuries either direct or indirectly. The development in sports and recreation activities need the involvement of knowledgeable, skilled and qualified personnel in order to offer various products and services to the society. The products and services offered could develop a competitive and precise economy to the nation. Sports and recreation activities as well as others could offer new business prospects, services and latest products. The objective of this article was to look into and explain how risk management practices through sports and recreation activities could help assure and secure the quality and wellbeing of a society.
\end{abstract}

Keywords

Risk Management, Practices, Sport, Recreation

Subject Areas: Education, Sports Science

\section{Introduction}

Risk management has been developed as a concept from the 1950s and was started in activities related to space programs, financial and nuclear energy [1]. Another is the early development of risk management in the insur-

How to cite this paper: Zakaria, J., Harun, M.T., Salamuddin, N. and Taff, Md.A.Md. (2016) Risk Management Practices towards Developments of Sport and Recreational Activities in Malaysia. Open Access Library Journal, 3: e2681.

http://dx.doi.org/10.4236/oalib.1102681 
ance industry and it is then used for other disciplines such as construction project, clinical, medical, energy and operational risk management [2]. Risk management has also been included in the field of sport and recreation and a part of today's most important element altogether include budgeting, scheduling, insurance coverage, eligibility, equipment and facilities management, contract and other tasks [3].

Risk management is a key factor that influences and gives implications on the security status and of course can lead to injuries. The increasing accident rate in the vicinity of sports and recreation can give adverse effects on the industry. This prevailing trend is giving an impact on the industry which could cause the industry to bleak due to the absence of demand in organized activities [4].

Arising problems related to security and injury issues were caused by various factors in risk management practices such as no monitoring of the tools, extremely old facilities, less qualified coaches, non-field trainers and did not provide proper medical facilities [5].

The scenario in Malaysia, problems related to the practice of risk management, has become a concern and cases related injuries are getting covered by the media. Given the high frequency of accidents in sports programs, it has caused many negative complications. These negative complications are concerning parents and guardians to allow their children to engage in sports and recreational activities for fear of the risk of injury [6].

\section{Background}

Well-managed and organized sports and recreation services can help minimize the security associated risks to the individual and the participants involved. There are many studies that have been conducted in the field of risk management that explain the importance of good risk management practices can avoid the risk of injury on participants and individuals. Normally, this scenario that can be seen in Malaysia itself are monitoring actions, maintenance and management planning that were created in order to avoid accidents and injuries [7]. Meanwhile, studies related to risk management in sports and recreational activities are still scarce in this country [6].

Most studies conducted have proved that good risk management practices can avoid the risk of injuries. Through the research conducted, sports and recreations locations are among the places that have frequent occurrence of accidents and injuries [6]. Problems related to risk management practices are indeed indirectly affecting the involvement of individuals and communities in sports and recreational activities. If this matter is allowed to persist, feared that the government's campaign to encourage community participation through sports and recreational activities will be disrupted and thereby contribute to a variety of other social problems.

Feeling self and other physical body parts as healthy is also among the factors influencing the community to participate in sports and recreational activities. Individual safety level is different from each other and depends on the situation and the current environment. Safety can often be defined as a state that is free from the dangers inherent in an individual's environment. Safety is a condition in which the situation will not cause any risk of either an accident, injury or even death [8]. If safety is not taken care of then it will cause problems and calamities to individuals and society as a whole in activities conducted.

Problems related risk management practices and safety procedures either in services, sports and recreation industry are problems with the interest of the public in general. This is due to the lack of awareness of the management and is also influenced by the attitude of some people in society who are less concerned with security elements which can result in injuries. Several government agencies under the Ministry of Human Resources as National Institutes of Occupational Safety and Health (NIOSH) and the Social Security Organization (SOCSO) always organize campaigns, courses, guidance and advice on the importance of safety. This indirectly acts as a long term process in shaping the attitudes of individuals to be more concerned about the safety in each of the activities organized.

Sports and recreation field and industry in Malaysia absolutely require an ethical management practice, principles and positive risk management practices. The development of the positive elements will help propel the country's economic performance in the field of sports and recreational thus indirectly gives a strong impact on the country's sports tourism industry. According to [9], safety is an organization's core value in providing facilities and services to consumers.

Injuries and accidents in sports and recreational environment are inevitable if not handled properly. This obviously requires the authorities to build, implement and evaluate appropriate risk management policies. Good risk management practice is not a platform that can detect the number of accidents, but it only serves as a preventive measure in reducing the number of accidents that occur. Some accidents took place unexpectedly. 
Whatever the approach taken, users must somehow remain exposed to the risk. The method that can reduce the exposure to risk is to reduce the number of injuries that can be avoided. According to [9] facility managers see risk management practices amenities as very important and indeed may have wide implications for the service. This is in line with the industry that is absolutely dependent on the services should provide good quality services to ensure customer satisfaction [10]. A good relationship between quality of service and customer satisfaction has got great coverage in the research community and related services [11].

However, it is too difficult to set too many policies in the risk management practices due to constraints involving consumers and society itself. Apparent difficulties include sports and recreational facilities that have been worn and outdated, lack of risk management planning, lack of knowledge and lack of experienced and knowledgeable personnel in facilities management. Therefore, this paper will explore the further development of related risk management practices, theories of risk management that are often referred to and also risk management practices in sports and recreational activities.

\section{Risk Management Practices in Malaysia}

The development of sports and recreational activities has been started since the beginning of the era of Malaya itself. People at that time had begun to build creative and created games to fill a gap in their spare time. Among the traditional games, such as top spinning, sepak raga, long pole game and also kite flying [12], it is clear that sports and recreational activities have started back and then were expanding by the situation at that time. This may be because of the location of people and communities back then who lived near the river, the sea, the coast and the nearby hills and mountains. At that time, the youth got to play and experience sports and recreation in a real environment and those experiences can be implemented in their daily life.

The modern era of recreational areas has begun to flourish with the start of the British colonial government at the time. With the opening and construction of buildings in the highlands has fueled more recreational activities such challenges based on Bukit Larut (Perak), Cameron Highlands (Pahang), Fraser’s Hill (Selangor) and also Bukit Bendera (Penang). The vigorous recreational activities have been the establishment of National Park in Kuala Tahan, Pahang, formerly known as King George V National Park before the country gained independence. Activities in this area focus on challenge-based recreational activities such as mountain climbing, rivers and caves exploration and water activities.

The rapid growth and influence of sports and recreational activities have helped develop a strong sports and recreational services nationwide. The sequence of these developments and in 1983 former Prime Minister Tun Dr. Mahathir Mohamad launched the program called "Malaysia Cergas". This program focuses on the concept of a healthy lifestyle among Malaysians. With the introduction of this program, it has helped in terms of development and construction of sports and recreational facilities in Malaysia and boosted the sports and recreationbased services. The funds have been channeled through the Ministry of Youth and Sports to build a variety of sports and recreational facilities [13].

The effect of the "Malaysia Cergas" program was that various infrastructure and facilities have been built and upgraded in accordance with local requirements. Among the effects are sports and recreational facilities open concept such as artificial wall climbing, volleyball courts, skateboarding arenas, BMX stunt courts and many others. The indoor facilities are also characterized as gymnasium, badminton courts and others. All costs to build and provide all these were costly and require safety features of quality, particularly high activity elements such as artificial wall climbing. Negligence and shortcomings while carrying out activities will lead to the occurrence of accidents that should not happen.

Based on these huge funds as well, the ministry through its departments throughout the country has undertaken various initiatives in assisting the development of sports and recreational activities. Through a variety of programs that have been conducted, the resulting products are also included in "Malaysia Cergas" program and among the Rakan Muda programs and courses related to the organization of sports and other recreation.

The contribution and involvement of the Ministry of Youth and Sports undoubtedly have assisted in the development of sports and recreational activities. With this development, the number of union-oriented sports and recreational activities has been established. Among them are the Football Association of Malaysia, Badminton Association of Malaysia, Malaysia Canoe Association, Malaysian Climbing Association, Malaysia Recreation Coaches Association, Malaysia Orienteering Association and many others. All of these associations work in developing the sports and recreation each specifically with financial assistance from the ministry. However, the 
union movement is limited by the funds provided by the ministry to carry out its activities and recreational sports. Nevertheless, with the limited offerings from the NGOs in Malaysia, the government took the initiative to build complexes of sports and recreational facilities for the public and local communities. Among such complexes are state youth and sports department, Rakan Muda complexes, gymnasiums, public futsal courts and gardens through the challenges that control the activities of extreme sports.

However, the wide impact of the development of sports and recreation and also with the involvement and participation of the public to some extent has caused some problems such as the aspect of control, safety equipment and so on. This is because the service offering sports and recreation is always closely linked to the sentiment of injuries and accidents. People and the environment is a global issue that has often debated by various segments of society [1]. This has revealed a correlation and interdependence clear between these two elements of capacity and service activities and recreational sports. However, if each of the activities is carried organizers often take for granted in terms of risk management. Thus, the facilities environment can also be a source of comfort to the cases of accidents and injuries when combined with other elements such as negligence and so on.

Injuries and accidents generally can be described as unfortunate events which may cause injuries, damages or disruptions in the process of teaching and learning [2]. If viewed in terms of service offering sports and recreation, the environment is a common element and potentially dangerous to the participants. However, the practice of risk management is an important pillar in carrying out activities in the sports and recreational facilities so that the people's environment is more prosperous and harmonious and free from the threat of injuries and accidents.

\section{Risk Management Theory}

Risk management practice is an important practice in the management of sports and recreational activities. It has already been given a special attention by researchers, academics, organizations and the government. Several widely used measured theories have been introduced by previous researchers in carrying out the measurement of risk management practices. Among the theories that are often discussed are Domino's Theory of Accident Causation, the Ferrell's Theory of Human Factors and Petersen's Accident Theory. A theory is the basic science knowledge that allows people to explore and understand the phenomenon more clearly and in depth, build strategy implementation and indirectly express proactive guides that can be taken to solve a problem or phenomenon. In addition, a clear understanding of the concept and role of a theory helps an individual to make the latest forecast of the probability that something might happen. A clear understanding of the theoretical aspects is important for those who work directly in the academic world. Scholars explain that absolutely clear understanding about the theory distinguishes between researchers and academic researchers.

The theory is a branch of science that has a mutual relationship between the variables that exist in a particular investigated phenomenon. The existence of each of these variables is a result of the prolonged and arranged investigations. The variables that were identified in a theory are often used as a hypothesis to investigate a phenomenon that will probably happen. The findings of the research hypothesis will be applied to either oppose, support or make improvements based on the existing theory. The implication is that the result can be applied in the process of life to improve the society's quality of life.

There are various theories can be associated with risk management that can be discussed together in carrying out an assessment. A theory which can be used in a way that is supposed to help a driver to avoid stray or drive down the wrong path [14]. A theory is also the sign or symbol that reflects the real condition or situation [15]. For him, this theory would explain the real situation in the form of a concise but very comprehensive manner. Among the experts who studied the effect of the law on leisure is [16] [17], sports and physical education [18] [19], event management [20] [21] and sports facilities [4] have developed a committee which acts as a guideline for implementing programs and activities that are free from risk. In this study there were three theories of risk management that will be used as the basis for this study.

\subsection{Domino's Theory of Accident Causation}

This theory was introduced by Herbert W. Heinrich who at the time served in one of the insurance firms. In 1920 , it was estimated that he had begun to study the reports of 75,000 cases of industrial accidents and he made some conclusions, namely 1) 88 percent of accidents are caused by unsafe acts committed by employees, 2) 10 percent of accidents are caused by not safe circumstances and 3) 2 percent of accidents due to causes that cannot 
be avoided.

Based on the findings of the study, he defines an accident as something which is not designed and cannot be controlled even during the reaction to an accident, objects, people, materials or the probability that is possible to occur. Heinrich said that the theory of the cause of the accident is the relationship between people and facilities, frequency and severe relationship, of unsafe acts, the management's role in preventing accidents, the cost of accidents and the impact on the efficiency of security.

Heinrich has developed the Domino's accident theory based on five in sequent factors namely:

1) Compliance and social environment: that is the process of knowing the customs and culture as well as skills in the work environment. Lack of knowledge and poor skills in carrying out duties, poor social interaction and environmental conditions will cause people to make mistakes.

2) Individual's negligence: negligence and mistakes made by an individual gives the characteristics of the individual's negative personality, however, features that are not needed will likely occur and the result from the negligence is an act or unsafe condition.

3) Act or physical facilities are not safe: these factors include technical mistakes and weaknesses that led to the accident.

4) Accidents: accidents are caused by acts or unsafe conditions that led to the injury.

5) Injuries: as a result of accidents.

\subsection{Ferrell's Theory of Human Factors (1997)}

This theory was introduced by Doctor Russel Ferrel in 1997. He believed that human error is the main cause of most accidents. Accidents are caused by several factors, namely the excessive burden, inappropriate reactions and activities that are not appropriate. The factor of excess capacity responds to the incompatibility between the load and the ability of human beings. Results that were obtained from these factors are anxiety, stress, fatigue and emotion. The factor of an individual's wrong reaction is when an individual who is involved in less appropriate situations and environments. The factors of less appropriate activities is in which individuals are engaged in a way that one is likely to be caused by a lack of knowledge about the activities or indeed willing to take risks.

\subsection{Petersen's Accident Theory}

Petersen's accident theory is one theory that is built based on management system and not based on the individualistic alone. This approach refers to the weaknesses in the management of an organization, causing an accident. Petersen has listed three essential elements in his theory which is the ergonomics trap element, the decision that encourages error and system failure. He has prioritized that a system failure is a major contributor in this theory. The system refers to the management system implemented in the security aspects of an organization. The system would indeed involve the management of the organization as the responsibility of the organization to ensure that all regulations and guidelines are appropriate and complied with suitability.

In this theory, Petersen has described some related failure of the system:

1) There was no serious participation of employers and management in the aspect of security risk management.

2) The management does not provide a complete risk procedure and security in the organization.

The management did not explain clearly the responsibilities and risks related to enforcement and security.

3) Risk management procedures and safety within the organization is not observed either in terms of monitoring, implementation and maintenance which was not carried out correctly.

4) Technical training programs are not provided sufficiently.

Petersen has made it clear that the organization is a contributing factor to the accident. This includes policies and lax safety procedures, no adequate training, monitoring systems and do not follow the guidelines that have been set. These factors have the potential to cause accidents and injury to individuals. He emphasized that awareness and action should always be taken seriously by the management of the organization.

Based on the discussion of the three theories, it is clear that elements of the human, equipment and environment play an important role in risk management practices. All three of these factors have connection with each other in the vicinity of sports and recreational activities. 


\section{Risk Management Practice in Sports and Recreational Activities}

Each approach requires a clear process and can have implications in terms of management of the organization. Without a good process, it will indirectly affect the objectives of the organization. Based on the method of practice in risk management, there are three risk management processes that are taken as the main source for managing risks, namely 1) identify risks, 2) evaluate the risks and 3) risks control.

The process of identifying risks implies checking which sources such risks come from. In this process also the type of risk should also be determined to facilitate managers in identifying risks that exist. The method is often used to make the initial survey in the vicinity of the affected facilities and two-way communication with the users' convenience. There are five categories that are likely to have risky probabilities. First, sports and recreational facilities such as playgrounds, gymnasiums, high level ropes activity facilities and swimming pools can indeed pose a risk of accidents. Examples such as an uneven tennis floor and a hole could result in danger to fall and indirectly lead to injury.

Second, the equipment that has expired or has not been used yet is necessarily harmful and poses a risk of injury and accidents to users. High element activities such as artificial wall climbing, used ropes and over a period of use cannot be reused and must be exchanged with new ones because the kernmantel type of rope has a certain lifespan [22]. Similarly with other equipment such as machine tools burdens in the gym if they are damaged and are still left there will invite accidents for users in the end.

The third category is related to the officer or officer-on-duty who are qualified and have skills. Most facility complexes absolutely did not put those qualified officers to manage the sports and recreational facilities. Most cases of accidents occur as a result of lack of supervision, unclear communication and did not have a complete plan in responding to the accident and emergency.

Furthermore, information about the participants in the activity must be identified. For example failure to submit information relating to the health records or biodata will lead to information about the risks that may occur cannot be identified. Of course, the facility management cannot determine the level of physical preparation before undertaking a user facility or use the facilities there. While the latter is related to programs or activities that are organized. For example, indeed that patterned or activity-based challenges such as kayaking in the rapids or white water rafting activities are foreseeable risks such as drowning and upside down kayak or capsize.

Each category discussed is a summary of all procedures for the management of an organization that manages a facility or providing sports and recreational activities. Indeed, if management has the skills to identify the risks inherent in each of those categories at once to give clear guidance in predicting the likelihood that will happen. This can indirectly impair the management of the organization and thus invite a loss either to the user or facility management.

However, risk assessment is of course easier if the management has information regarding users who are well-equipped. However, if the management does not have all the data and information related to the user, management should use all the existing and learned experience and make an assessment of the risks that have been identified. Existing experience can assist management in dealing with a particular situation in a more systematic and effective way.

In the process of evaluating the risks, the most important principle is to determine what the priority level of each risk is. Clearly, in determining the level of risk involved requires a combination of two entities, the frequency of occurrence of harm and the likelihood of a severe impact from the occurrence of such hazards. The combination of these two entities will determine the priority of a risk assessed.

The latter process is risk control itself. After identifying the level of risk, risk assessments have been carried out. The next process is to determine the methods or ways to treat and control these risks. Normally there are four strategies outlined in the risk control techniques that retain, avoid, reduce and transfer [16].

The strategy of risk control is by accepting that risk without doing anything. However, such a strategy is only suitable for risks that are not harmful or very small. For example, natural risks cannot be avoided in the activities organized. Such a strategy can also be applied if the responsible management is willing to pay compensation in the accident or loss that has been suffered by consumers.

The second process is to avoid the risk (risk avoidance), namely by avoiding overall potential risks. This is one way so there could not be a definite loss. This type of strategy is very suitable to be used if the risks to be experienced are very severe if it occurs. As one example, football cannot be carried out due to the strong rain and lightning. Through this method, the potential risks of such players from getting struck by lightning will be 
inevitable from happening.

The next strategy is to control the risk that is motivated to reduce or lower the levels of frequency and severity of accidents from happening. This strategy see that if profit can be obtained and the constraints that will be encountered if the facilities inherent risk of accidents continue to be used. However, in the context of management in providing the best facilities to the public every facility used has risks of its own. However, it is a disadvantage if risk facilities continue to refrain from being used in order to avoid the risk of the occurrence of the accident. This is a step that is less accurate and less intelligent in the aspects of risk management. In reducing the risk of accidents associated facilities, the management can use methods such as;

1) Policies or security guidelines that clearly must be provided and can be used as a reference by all parties involved in either the user or facility management.

2) Inspection of facilities and equipment should be carried out in a prudent and well planned in order to avoid problems in the future.

3) Officers or staff who are directly involved with the facility should be trained and given training relating to any aspects so that risk management procedures and risk practices are followed.

4) Installation of clear warning signs in places that it considers the potential risk of accidents.

The last strategy is, the transfer of risk or transfer risk to another party. Indeed, this strategy puts the management in a comfortable condition. This is because all the responsibility for any losses and the consequences of the risk is transferred to another party. Purchase of insurance policy is an accident and the use of such documents (liability waiver form). This strategy is one of the options in the management of issues related to unravel the risk in their facilities.

Obviously, all the organizations that offer products and services to consumers should have a responsibility to ensure a safe and conducive environment for consumers' convenience. The management must have employees or staffs who have clear knowledge about aspects of risk management. They need to have a treatment that always has the nature of the alert and in accordance with established procedures. The treatment that did not reach a clear and standard manner would surely lead to carelessness and eventually will lead to the risk of accidents.

Thus, risk management is the best approach to ensure the safety of consumers and the public is assured. This indirectly allows them to conduct their business in a safe and secure condition. Some positive practices in risk management and is geared to discuss the relevance of the theories of risk management. Some of these practices is the process of inspection, maintenance procedures, personnel management, emergency plans, facility design, program management, user information and also insurance policies.

\subsection{Inspection Process}

The inspection process is a key element in managing and reducing the risk of injury and accidents [23]. In this study, a systematic examination process by the personnel can help prevent injury and accidents on the sports and recreational facilities. Inspection and maintenance is necessary if there are any signs of damage or can be detected which will cause damage and disability. If this process is not completed or carried out, it will cause unwanted things like accidents, damages and the like either to the long-term or otherwise [9]. While [24] in research related to risk management practices of physical education activities explain that perfect management in each program can have a positive impact on user but otherwise a risk of injury. Tools and facilities should be checked and confirmed to be in good condition, if damaged should be repaired or replaced with new ones to maintain the quality of services at the facility. According to [25] facilities and equipment should be interesting, easy and economic aspects of its implementation in order to attract users to conduct more motivated activities.

\subsection{Maintenance Procedure}

Maintenance is an important aspect related to the management of sports and recreational facilities. The work is done for maintaining equipment and facilities in good condition [26]. In this study, refers to maintenance work carried out to repair and fix damaged facilities and equipment in order to use and work well. The maintenance process needs to know and understand in order to identify any characteristics and traits of damage to determine the appropriate maintenance system, the maintenance of proper conduct and analyze the implementation process [9]. According to [27], in implementing the organization must have a staff that is effective, efficient training, schedule an organized plan, and complete adequate financial records. This must be taken into account to achieve the goal of giving services that are always punctual, quality maintenance and work to ensure first-class in all as- 
pects at all times. Supported by [28], explains that in order to meet the needs of maintenance management must have complete knowledge about the assets, mainly on asset condition and performance of the services rendered to the quality of maintenance at its best.

\subsection{Staff Management}

The staff is the human resource working in an organization in various levels of management. In this study, the staff refers to staff working at the state's JBS complex facility and Rakan Muda Complex in Malaysia. Employees are efficient, reliable and responsible about the scope of work and duties to help the organization improve its performance [29]. Experienced staff and have a clear knowledge about the scope of his work can help the organization minimize the risks. According to [18], the most larges equipment in minimizing risk is to ensure that staffs have always received instructions and the latest information on risks. The staff is well trained to help and take care of the problem by helping organizations monitor the work as construction of facilities, building security issues and to report to the employer if there are any problems. Monitoring early as this can help organizations of legal action in case of any untoward incident as the initial information has been obtained from the staff.

\subsection{Emergency Plan}

The emergency response plan or emergency plan is a system where if there is an accident or disaster, responsible staff can perform actions according to the systems and procedures that have been set [30]. In this study, emergency plan or system refers to the method used by the staff at the sports and recreational facilities in the event of an accident involving the user. According to [31], the emergency plan should be developed by the employees of the organization or institution with regard to the needs of local emergency agencies. Components of the plan include identifying emergency response personnel, equipment specifications needed to respond to emergencies, and the establishment of a communication system to contact in case of emergency. Emergency plans should be reviewed and updated annually with written documentation. The plan should identify responsibilities for documentation of actions taken during the emergency, emergency response assessments, staff training institutions as well as related equipment and facilities.

\subsection{Facilities Design}

The design features are associated with the services provided which have security features that have been designated by the responsible agencies. It also deals with the placement of sports and recreational facilities in place. According to [18], various state laws, the definition of the court, and the interpretation of the general construction defects and design defects of this facility can be divided into four categories, namely the lack of design, lack of materials in the construction, weakness in the construction and floor surface problems. According to [32], architects, engineers and consultants have begun to adopt social responsibility by incorporating the concept of a good facility design and technology for the benefit of projects to their customers and indirectly sport and recreation professionals can benefit by getting adequate facility.

All these aspects need to be given attention by the management in providing a facility that no court action in case of any untoward safety in sports and recreational facilities. In the case of [33] in South Wales, Australia, the plaintiffs claimed that he had fallen from a ladder at the fitness center operated by Loose Fit Pty Ltd, he fell and suffered injuries to his left shoulder. Details are as a result of negligence and breach of duty of care that has been taken by the Loose Fit because it does not provide a handrail installed on the staircase. Whereas in the case of [34], the plaintiff was injured due to the weight training. The plaintiff made several claims of negligence such as not providing sufficient space activities weight training, do not give proper instructions on the use of equipment and staff that makes inadequate supervision, lack of skills and unqualified. Cases like these are absolutely true and management cannot take it easy on consumers' safety.

\subsection{Management of the Programme}

The program management element is one of the factors that affect an individual participating in the activities organized. In this study, program means whatever program sponsored in sports facilities will give positive implications for consumers and individuals. Weaknesses in the management of the program will provide a variety 
of negative implications on the program. According [35], a good program management can improve the quality of the organization of management aspects. Management skill is a prerequisite in ensuring the success of a program.

\subsection{User's Information}

In the context of this research, consumer information refers to charging a user's personal information before using any sports facilities and recreational amenities. The management also provide liability release form to be filled by the user before using the facilities provided to prevent acts of insurance and so on. Liability release form (Waiver and liability form) is absolutely applicable to the transfer of liability to the insurance organization. However, management cannot take in the event of an injury to the user if caused by the negligence of the management of the facilities.

However, the form information is used to reduce the cost of the organization in the event of loss of the plaintiff's claims for damages. Form discharge this responsibility should be clear and well before the use should be referred to a lawyer who specializes. In the case of cell [36], the form of abdication of responsibility is not complete and the court rejected the argument put forward by the cell Pty Ltd. According to [5], the staff is efficient and versatile should be exposed with the appropriate information on an ongoing basis in order to execute all commands and work that has been given by the management.

\subsection{Insurance Policy}

An insurance policy is a document that contains a contract of insurance and it contains an action plan which has been agreed formally as the basis for making a decision or action. In this study, the insurance policy refers to the practice of registration of insurance policy before an activity is carried out either on staff or users of sports and recreational facilities. An insurance policy is very important to the participants nor the management. According to the [37], the implementation of treatment and prevention is the best in dealing with risk is to buy insurance policies that are appropriate to the activity or program. The insurance policy is one method of transferring management to the third party liability insurance. This can indeed help the management of large losses if forced to pay damages resulting from non-term negligence.

\section{Conclusion}

Through this explanation, it is clear that risk management practices are able to provide various positive effects on the quality and the welfare of society through sports and recreational activities. Safety of course is the right of every individual to feel safe without any anxiety when conducting activities and also in everyday life. The safety aspect is translated into something more systematic and organized through risk management practices. Risk management is very important in everyday life and especially in the management of sports facilities and recreation. The weakness of the aspects of risk management will result in bad and negative implications for the organization. According to [38], sound risk management can reduce the cost of the organization and at the same time give a positive edge to the organization in the eyes of consumers. Effective risk management should take into account all the elements of the necessary foundation for more systematic procedures. A conducive environment could be created if all the elements of risk management practice and thus users will feel safe and comfortable during the activities.

\section{References}

[1] Erten, S. (2008) Insight to Ecocentric, Antrhropocentric and Antipathetic Attitudes towards Environment in Diverse Cultures. Eurasian Journal of Educational Research, 33, 141-156.

[2] Hollnagel, E. and Goteman, Ö. (2004) The Functional Resonance Accident Model. Cognitive Systems Engineering in Process Control, Sendai, Japan, 4-5 November 2004.

[3] Australian Sports Commission (2002) Risk Management for Directors and Board Members of National Sporting Organizations: Standards Australia International.

[4] Mulrooney, A.L. and Farmer, P.J. (1998) Law for Physical Educators \& Coaches. 2nd Edition, Publishing Horizons, Ohio. 
[5] Noe, R.A. (2009) Employee Training and Development. 5th Edition, McGraw Hill, Boston.

[6] Mohamed, M., Fauzee, M.S.O., Soon, L.T., Jusoh, Z. and Zainudin, R.J.A. (2006) Persepsi Guru Sukan Terhadap Aspek Keselamatan dalam Program Sukan. Asian Journal of University Education, 2, 1-20.

[7] Abdullah, J. (2014) Majlis Bandaraya Petaling Jaya (MBPJ) di Rayu Baiki Kemudahan Taman Permainan: Utusan Malaysia.

[8] Rafiin, M.A. (2005) Keselamatandan Kesihatan di Malaysia. Penerbit Universiti Teknologi Malaysia, Skudai.

[9] Sharp, L.A., Moorman, A.M. and Claussen, C.L. (2010) Use of Waivers and Exculpatory Clauses: Sport Law: A Managerial Approach. 2nd Edition, Holcomb Hathaway Publishers, United States.

[10] Shemwell, D.J., Yavas, U. and Bilgin, Z. (1998) Customer Service Provider Relationships: An Empirical Test of a Model of Service Quality, Satisfaction and Relationship Oriented Outcome. International Journal of Service Industry Management, 9, 155-168. http://dx.doi.org/10.1108/09564239810210505

[11] Sureshchandar, G.S., Rahendran, C. and Anantharaman, R.N. (2002) The Relationship between Service Quality and Customer Satisfaction: A Factor Specific Approach. Journal of Service Marketing, 16, 363-379. http://dx.doi.org/10.1108/08876040210433248

[12] Daroji, I. and Chia, C.M. (2012) Pendidikan Luar. Penerbitan Multimedia, Puchong.

[13] Taff, Md.A.Md. (2012) Manual Pendidikan Kanu Kebangsaan. 2nd Edition, Penerbit UPSI, Tanjung Malim.

[14] MKenzie, M. (2000) How Are Adventure Education Program Outcomes Achieved? A Review of the Literature. Australian Journal of Outdoor Education, 5, 19-28.

[15] Hill, A. (2012) Developing Approaches to Outdoor Education that Promote Sustainability Education. Australian Journal of Outdoor Education, 16, 15-27.

[16] Kaiser, R.A. (1986) Liability and Law in Recreation, Parks, and Sports. Prentice-Hall, Englewood Cliffs.

[17] Van der Smissen, B. (1990) Legal Liability and Risk Management Entities. Anderson Publishing Co., Cincinnati.

[18] Seitter, D. (2006) Managing Risk through Employee Training. Proquest Education Journal, 100, 74-76.

[19] Head, G. and Horn, S. (1991) Essentials of Risk Management. Insurance Institute of America, Malvern.

[20] Brown, D.W. (1996) Facility Maintenance-The Managers Practical Guide and Handbooks. American Management Association, New York.

[21] Fried, G. (1999) Safe at First: A Guide to Help Sport Administrators Reduce Their Liability. Carolina Academic Press, Durham.

[22] DiMartino, T.J. and Sandwith, C.J. (2009) Proper Care, Maintenance, and Inspection of Climbing Ropes to Reduce Degradation and Help Determine When to Retire Them. Proceedings OCEANS 2009, MTS/IEEE Biloxi-Marine Technology for Our Future, Biloxi, 26-29 October 2009, 1-8.

[23] Sekendiz, B. (2011) An Investigation of Risk Management Practices in the Health and Fitness Facilities in Queensland. Ph.D. Thesis, University of Bond, Gold Coast.

[24] Miller, J.J. and Gary, J. (2003) Risk Management Practices of University Physical Education Activity Supervisors. Journal of Legal Aspects, 12, 117-130.

[25] Leong, K.C. (2004) The Essence of Good Facility Management: A Guide to Maximization of Facility Assets Economic Life and Assets Optimization for Reliable Services and Users Satisfaction. Buletin Ingenieur, 24, 7-19.

[26] Gulhane, T.F. (2014) Need for Advanced Facilities and Equipment in Physical Education Colleges. Journal of Sport and Physical Education, 1, 48-49.

[27] Hsio, R. (2005) Analysis of Risk Management Practices and Litigation Status in Aquatic Centers. Ph.D. Thesis, University of Florida, Gainesville.

[28] Clement, A. (2004) Law in Sport and Physical Activity. 3rd Edition, Sport and Law Press, Dania.

[29] Bucher, A.C. and Krotec, L.M. (2002) Management of Physical Education and Sport. McGraw Hill, New York.

[30] Kristin, L.S. (2005) The Effect of Supervisor's Trust of Subordinates and Their Organization on Job Satisfaction and Organizational Commitment. International Journal of Leadership Studies, 1, 86-101.

[31] Idrose, A.M. (2008) Pelan Tindakan Kecemasandan Bencana HKL 2008. HKL, Kuala Lumpur.

[32] Anderson, J.C., Ronald, W.C., Douglas, M.K. and Todd, A.M. (2002) National Athletics Trainers Association Position. Statement: Emergency Planning in Athletics. Journal of Athletics Training, 1, 99-104.

[33] Gibson, F., Lloyd, J., Bain, S. and Hottel, D. (2008) Green Design and Sustainability in Sport and Recreation Facilities. The Smart Journal, 4, 26-33.

[34] Loose Fit Pty Limited v Marshbaum and Ors (2011) NSWCA 372. 
[35] Mannone v Holiday Health Clubs and Fitness Centers (1992) 92 CV 0707.

[36] Othman, R. (2001) Pelaksanaan Program Pengurusan Kualiti. Jurnal Pengurusan, 20, 111-124.

[37] Berlonghi, A. (1990) The Special Event Risk Management Manual. Alexander Berlonghi, Dana Point.

[38] Belna Pty Limited v Irwin (2009) NSWCA 46.

- Publication on a daily basis

- 9 subject areas of science, technology and medicine

- Fair and rigorous peer-review system

- Fast publication process

- Article promotion in various social networking sites (LinkedIn, Facebook, Twitter, etc.)

- Widely-targeted and multidisciplinary audience to read your research

Submit Your Paper Online: Click Here to Submit

Contact Us: service@oalib.com 